AL-TA'LIM JOURNAL, 23 (1), 2016, (37-51)
(Print ISSN 1410-7546 Online ISSN 2355-7893)
Available online at http://journal.tarbiyahiainib.ac.id/index.php/attalim

\title{
Employing Graphic Organizers through Team-Pair-Solo Strategy to Improve Reading Comprehension of Eighth Graders at SMPN 9 Kubung
}

\author{
Lina Satriyani ${ }^{1}$ \\ Graduate Program in English Language Teaching, State University of Malang (UM) \\ East Java, Indonesia \\ E-mail: linasatriyani@gmail.com
}

Arwijati Wahjudi Moerdibjono

Graduate Program in English Language Teaching, State University of Malang (UM) East Java, Indonesia

E-mail: Arwijatwahyudi@gmail.com

Johannes Ananto Prayogo

Graduate Program in English Language Teaching, State University of Malang (UM)

East Java, Indonesia

E-mail: johannes@yahoo.com

\section{Received: $15^{\text {th }}$ February 2016; Revised: $24^{\text {th }}$ February 2016; Accepted: $28^{\text {th }}$ February 2016}

\begin{abstract}
This research was conducted to improve the students' reading comprehension by employing graphic organizers through Team-Pair-Solo strategy. Classroom Action Research which involved 32 eighth graders was employed in this study. The instruments were reading comprehension test, observation checklists, field notes and questionnaire. The steps done in employing the strategy were: (1) working in group in comprehending the text, (2) discussing the answer, (3) working in pairs,(4) creating their own graphic organizers, (5) swapping their work (6) giving feedback, (7) discussing the feedback (8) revising individually, (9) retelling the text by using their graphic organizers. The findings of this study showed that the strategy improved students' ability; most of the students (87.5\%) were actively involved and enthusiastic in teaching-learning process; and most of them (90\%) gave positive perceptions toward the implementation of the strategy. These results indicated that the strategy was effective in improving students' reading comprehension ability.
\end{abstract}

Keywords: Graphic Organizers; Team-Pair-Solo; Reading Comprehension

How to Cite: Satriyani, L., Moerdibjon, A., \& Prayogo, J. (2016). Employing Graphic Organizers through Team-Pair-Solo Strategy to Improve Reading Comprehension of Eighth Graders at SMPN 9 Kubung. A/Ta Lim Journal, 23(1).

doi: http://dx.doi.org/10.15548/jt.v23i1.173

Permalink/DOl:http://dx.doi.org/10.15548/jt.v23i1.173 
Kubung, the students' ability in English in general was still low though they are in the ninth grade, especially their ability in reading and writing. One evidence could be seen in their achievement in pre- and National final Examination. Based on the data of the result of prenational examination (Pra-UN) and national examination (UN) in academic year 2013-2014, it was found that more than $50 \%$ of students did not pass the pre-national final examination for English subject. Furthermore, more than $75 \%$ of students got the score below 50 in national examination. Besides, more than $50 \%$ of students in all grades in this school got low achievement in reading tests, under minimum passing grade of 70 during the semester. This meant that the students had not mastered skills developed in reading skills.

Moreover, it could also be seen in learning process at school. According to researcher's and her friend's experience in teaching students in that school especially in eighth grade (one class only), there were many kinds of difficulty faced by the students in getting comprehension whenever they read texts. Many eighth graders of academic year 2014-2015 had difficulty in finding general idea of the text they read. Besides, they also could not find the main ideas and supporting details for each paragraph in the text. Often, it made they got difficulties in identifying the information from the texts. Most of them only read the text word by word and translated that was new for them and tried to identify or making inference by themselves. Unfortunately, when they encountered some problems in comprehending the text and could not solve the problems alone, they might stop comprehending it. Then, many times it led them into a frustrated feeling because they got nothing except meaningless text and failure in comprehending texts whenever they were asked to read texts. However, there was a tendency that it would be better when they did it in small groups because they like working in groups.

Referring to the facts above, it was assumed that eighth graders had not been able yet in implementing the skills needed in reading an English text although the teachers had taught them some of those skills and teachers usually took more times to teach reading than teaching the other skills. Perhaps, this also meant that the students had not learnt how to read a text, though their teachers had taught them many times. Humboldt in Kumaravadivelu (2003:44) says "We cannot really teach a language; we can only create conditions under which it will develop in the mind in its own way." Therefore, the students often complained that they could not comprehend the text effectively because they had not learnt what the teachers taught.

Based on the observation done by researcher when she taught in that school, her friend's experience in teaching, and informal interview with some students from grade eight academic year 2014-2015 in February 2015 , the researcher assumed that low achievement and the problem of having difficulties in comprehending the texts above was probably due to a number of potential sources. They came from the side of the students such as lack of motivation to read, ignorance of reading strategy or lack of practice, unrealistic expectations of how much they should be able to understand. Then, they were also from the teachers' side; inadequate and interesting classroom techniques for teaching reading using by the teacher, lack of demonstration 
done in the class, insufficient material used to develop all reading skills, and lack of structures and infrastructures that can supports teaching learning process itself.

To overcome all of the eighth graders' difficulties, the researcher argued to use graphic organizers to improve students' ability in reading comprehension through team-pair-solo strategy. Richards and Renandya (2002:289) suggest that strategies help the readers to process the text actively, to monitor comprehension and to relate what they are reading to their own knowledge and to other parts of the texts. So, it was hoped that by learning this strategy students could improve their ability in reading that was by employing graphic organizers through team-pair-solo.

\section{METHOD}

Since this research was proposed to improve the students' reading comprehension by implementing graphic organizers through team-pairsolo strategy, the research design that was used was Classroom Action Research (CAR). Latief (2013:143) says that CAR for English learning aims at developing a certain instructional strategy to solve practical problems in English classroom, and at discovering learning-teaching strategies that match learners' style and strategies in learning English. CAR is an enquiry which is carried out in order to understand, to evaluate a problem that occurs in the classroom and then to make change to the better improvements of educational practice.

In implementing the CAR, the researcher adapted the model proposed by Kemmis and Mc Taggert in Latief (2013:146) that involved four broad phases namely planning, acting, observing and reflecting in one cycle. It started with problems identified that could be still improved through certain strategy to get better achievement in that problem by conducting next cycle with revised planning. So, the first cycle might become a continuing, or iterative, spiral of cycles which recurred until the researcher achieved a satisfactory outcome in solving her problem. This procedure is as shown in Figure 2.

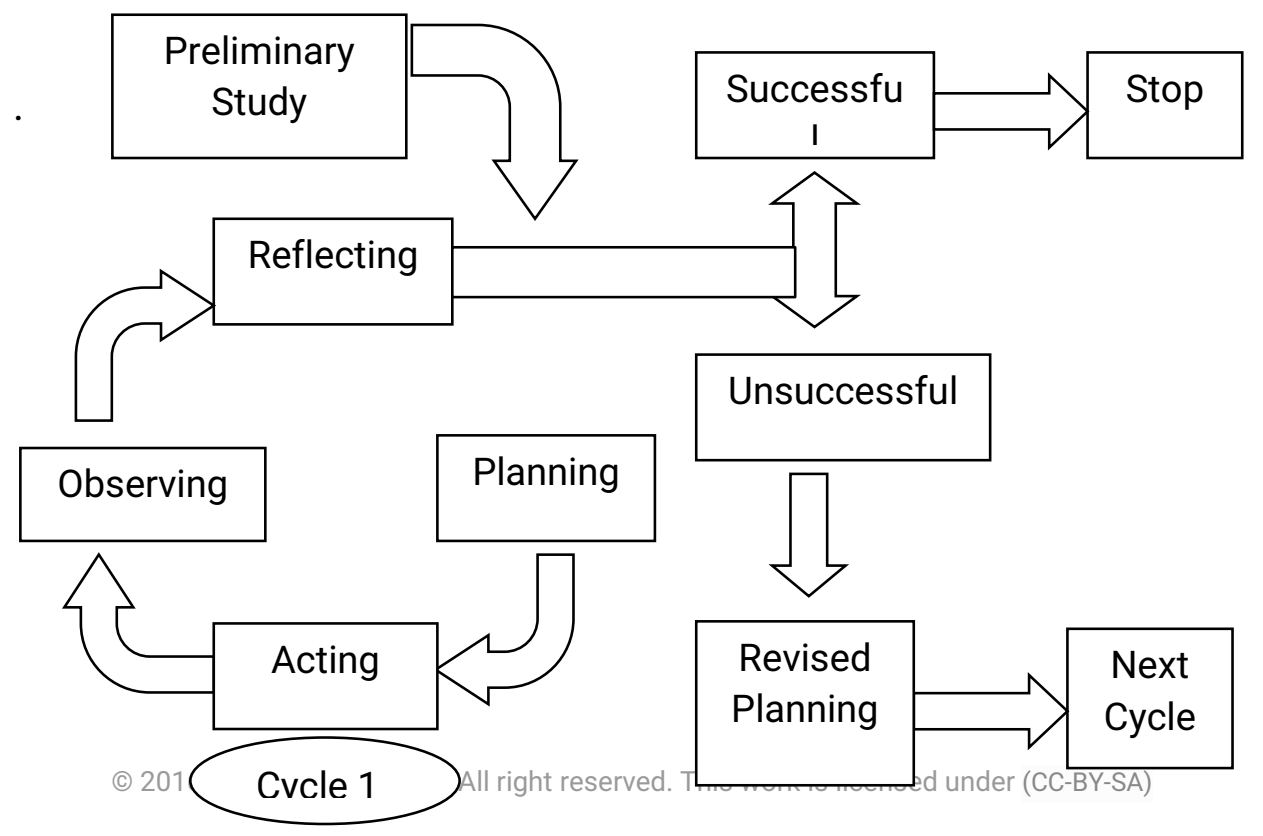


Figure 1: The Classroom Action Research Model Adapted from Kemmis and Mc Taggart in Latief, 2013:146

\section{Preliminary Study}

Before conducting the research, the researcher carried out a preliminary study to identify the students' problems in the classroom of the eight graders of SMP N 9 Kubung especially in reading comprehension. The data for preliminary study was collected from preliminary study test done by the researcher and interview with the teacher and some students. Based on the test, there were only 8 students or $25 \%$ got the score above the minimum standard of passing grade. The result showed that the students have difficulties and problem in recognising the general idea or topic of the texts and also in recognising main ideas in the texts they read. They failed to find the relationship of an idea with another ideas in the texts so they failed to comprehend the text as a whole. Teacher also said that the eighth graders relied on dictionary to comprehend the text by translating every word in the texts. However, they still could not get a comprehensible understanding about the text which then it was become one of their reasons for being desperate in reading Table 1 : Teaching Strategy texts since translating is not one of reading strategies and translating is not easy too. Besides, it was found thet they were still not ready to work individually, this made them easy to feel desperate since no discussion could be done. This condition then created another problem that decreased students' motivation in reading which actually their motivation was low. From those results, it could be concluded that the students had many difficulties in reading for comprehension. These results then were used to set up planning the cycle.

\section{Planning}

In this phase, the researcher needed to conduct the following set of activities regarding the problems faced by the students in reading to comprehend, they were by designing teaching strategy, lesson plan, and preparing instructional materials. In this research, graphic organizers was used as medium and team-pair-solo as strategy. The teaching strategy which was applied in learning process is described in Table 1. 


\begin{tabular}{|c|c|}
\hline Stage & Main Activities \\
\hline Team & $\begin{array}{l}\text { - Students are asked to work in group of four } \\
\text { - Each group has to comprehend the text by answering some } \\
\text { questions given by the teacher related to the text, each member } \\
\text { of a group answers different question (leading questions), which } \\
\text { means one student answers one questions, after reading the text } \\
\text { individually and silently. } \\
\text { - Students in groups discuss the answer one by one and the topic } \\
\text { of the text (one student in group leads group discussion, she/he } \\
\text { is chosen by the teacher, they are high achievers based on the } \\
\text { data from preliminary study). }\end{array}$ \\
\hline Pair + GOs & $\begin{array}{l}\text { - After getting the topic of the text, students are asked to split into } \\
\text { pairs meaning there are two groups formed from one group. } \\
\text { - Each student rereads the text while they are creating their own } \\
\text { graphic organizers for the text they read and answer questions } \\
\text { based on the text. } \\
\text { (They can create any kind of graphic organizers they want based } \\
\text { on their understanding about the text freely based on the model } \\
\text { explained by the teacher in the first meeting) } \\
\text { - Then after they have finished their task, they swap what they have } \\
\text { made and read their friend's graphic organizers and discuss the } \\
\text { answers. } \\
\text { - They give feedback (compliment, correction, or additional } \\
\text { information) about them. } \\
\text { - Each pair does discussion about what their partners write in } \\
\text { her/his graphic or comment given by her/his partner in her/his } \\
\text { graphic organizer to get clarification about it.. }\end{array}$ \\
\hline $\begin{array}{l}\text { Solo } \\
\text { GOs }\end{array}$ & $\begin{array}{l}\text { - Then students work individually to make their work better based } \\
\text { on their friend's feedback. } \\
\text { - Last, teacher asks the students to retell the text by using their } \\
\text { graphic organizers orally in groups. }\end{array}$ \\
\hline
\end{tabular}

\section{Acting}

In acting, the researcher carried out the teaching learning process based on the lesson plan arranged in the previous step, planning, in the classroom. In implementing the action, the researcher became the teacher as well as the researcher. This acting needed four meetings for implementing the strategy

\section{Observing}

Observing of the action was conducted to collect data related to the 
implementation of teaching reading comprehension using graphic organizers through team-pair-solo strategy. The function of this observation was to see whether the strategy which was used in this study can solve students' problem in reading comprehension or not, as well as the students perception toward the teaching learning using GOs through team-pair-solo strategy.

There are two kinds of data collected, quantitative and qualitative. The quantitative data was the data gained using reading comprehension test. This data was in the form of number and reflected whether the teaching strategy using graphic organizers through team-pair-solo improved the students' achievement in reading comprehension. This test was given in the fifth meeting after the strategy had been implemented. To guarantee the test was valid enough, the researcher considered the validity of the test given. In this case, the researcher used theoretical evidence; construct and content validity.

The construct validity is concerned with the appropriateness of the task being measured. It was conducted by analyzing the objective of the test and the type of the test in which the students were asked to do the task. In this research, the test was given in the form of reading activity which the students were asked to answer 30 multiple choice questions based on the texts they read to measure their reading comprehension achievement.

The content validity, on the other hand, is concerned with the coverage of the materials or skills being tested. This was conducted by analyzing the content of the test and the materials required in English syllabus of the second year of the junior high school. Theoretically, the test was valid enough since the test items were constructed based on the learning objectives in teaching reading texts as stated in the lesson plan. The students were asked to answer questions individually related to the texts read to check their comprehension toward the texts such as identifying general idea/ main ideas/ specific/ implicit/ explicit information, determining reference, guessing meaning of word based on the context, identifying the structure and communicative purpose of the text.

The second kind of the data used in this research was qualitative data. This data was in form of description and function as the reflection of the students' perception toward the implementation of teaching learning process using graphic organizers through team-pair-solo strategy. To collect this kind of data, the researcher used observation checklist, field notes and questionnaire. The observation checklist consisted of some aspects in form of statements which reflected students' activeness in teaching learning process in scale one to four. Meanwhile, the field notes were needed to write anything related to students' activity which was not stated in observation checklist. This observation was done by the observer, one teacher from SMP N 9 Kubung. While, the questionnaire consisted of ten questions which described the students' opinion on the teaching learning process using graphic organizers through team-pair-solo strategy in reading activity. These questions were in multiple choice answers with four alternatives (strongly agree, agree, disagree and strongly disagree). All the data gained from the observation 
checklist, field notes and questionnaire were triangulated by the researcher and the observer.

Then, all the data gained in this phase were analyzed in the next phase. It determined whether this cycle of this classroom action research success or not in solving students' problem in reading for comprehension. There were two criteria of success that were used in this study; the result of students reading comprehension test and students involvement in teaching learning process (See Table 2). If those two criteria were not achieved, the action might be continued in the next cycle with some revisions based on data got from the first cycle.

Table 2: The Criteria of Success

\begin{tabular}{|c|c|c|}
\hline $\begin{array}{l}\text { Produc } \\
t\end{array}$ & $\begin{array}{l}\text { At least } 80 \% \\
\text { students pass } \\
\text { the minimum } \\
\text { passing score } \\
(70)\end{array}$ & $\begin{array}{l}\text { 1. Reading } \\
\text { comprehe } \\
\text { nsionTest }\end{array}$ \\
\hline $\begin{array}{l}\text { Proces } \\
\mathrm{s}\end{array}$ & $\begin{array}{l}\text { At least } 80 \% \\
\text { students are } \\
\text { actively involved } \\
\text { during the } \\
\text { process using } \\
\text { this strategy and } \\
\text { respond } \\
\text { positively toward } \\
\text { the strategy }\end{array}$ & $\begin{array}{l}\text { 1. Observatio } \\
\text { n checklist } \\
\text { 2. Field } \\
\text { notes } \\
\begin{array}{l}\text { 3. Questionn } \\
\text { aire }\end{array}\end{array}$ \\
\hline
\end{tabular}

\section{Reflecting}

In this phase, the researcher analyzed the data gained and drew the conclusion to determine whether the strategy was successful to solve the problem by using the criteria of success planned before. There were two kinds of data that were analyzed here, quantitative data gained from reading comprehension test and qualitative data from observation checklist, field notes and a questionnaire. All the data determined the success of the research. If it could meet the criteria of success, it meant that the strategy in teaching learning using graphic organizers through teampair-solo strategy in reading activity was successful to improve students' comprehension ability and the cycle can be stopped. However, if it failed to meet the criteria of success, this study should be continued to the next cycle, and the researcher had to evaluate why this implementation fail and revise it to get better strategy.

\section{RESEARCH FINDINGS AND DISCUSSION}

This study was done in one cycle only since the data got after implementing the strategy met the criteria of success made before conducting the study. Both quantitative and qualitative data showed that the strategy was successful in improving eight graders' reading comprehension ability. This cycle was implemented in five meetings including the reading comprehension test session at the end. It was conducted on May $8^{\text {th }}$ to May $22^{\text {th }} 2015$ by using five different recount texts. The time allocation for each meeting was $2 \times 40$ minutes.

\section{The Students' Achievement on Reading Comprehension Test}

From the result of the test given, it was shown that 32 students who 
joined the test, all of them had improvement in reading comprehension achievement if compared with the comprehension result in preliminary study, there was improvement of the students' average score, from 55 to 74.68 and number of students who passed minimal passing grade, from 8 to 26 students. Besides, all of low achievers in preliminary study, 24 students $(100 \%)$ made improvement 13 points or more and all of high achievers, 8 students (100\%) got 7 points as their improvement. Figure 3 presented the result of the students' reading comprehension test.

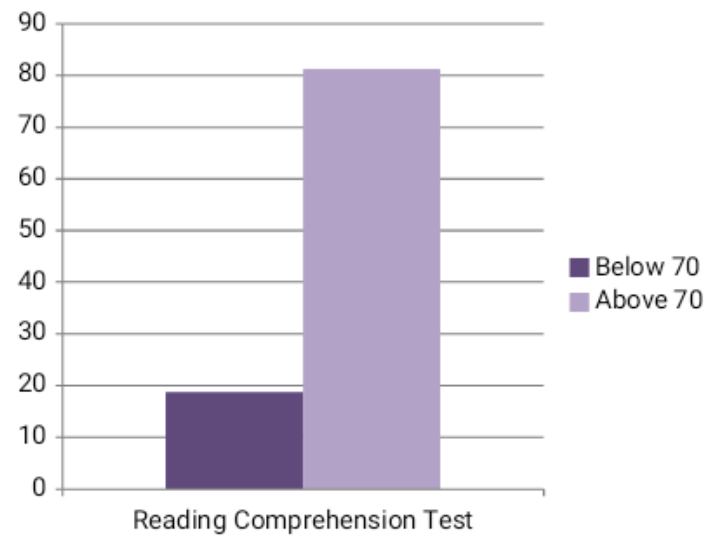

Figure 2: The Result of Reading Comprehension Test

Based on the findings of the students' achievement in reading comprehension test, it could be inferred that the implementation of graphic organizers through Team-Pair-Solo strategy give benefits in improving the students' reading comprehension ability. This improvement was indicated from the students' score in the end of the cycle, there was improvement of the students' average score, and number of students who achieved 70 or more and all of them made improvement after the strategy was implemented in teaching reading. Those findings were in line with Kim, Vaughn, et al, (2004) who affirm the use of graphic organizers were highly effective in improving reading comprehension. Besides, these findings supported the previous research findings done by Keene (2009) who says that making students feel successful can make them learn effectively which can influences their achievement in teaching-learning process.

This strategy obviously helped the students to know the text structure, make them easier in identifying main ideas and supporting informations of the text, then also help them in identifying referring pronoun, understanding the meaning of the words in the text, and its purpose Thus, the implementation of the graphic organizers through Team-Pair-Solo strategy in improving reading comprehension ability in the current classroom action research has shown as an beneficial strategy.

\section{The Students' Involvement in the Teaching-Learning Process}

The result of this data was collected from observation checklists and field notes done by the observer during the teaching learning process using the strategy in this study. It was conducted in each of four meetings . The data was collected to the researcher after discussing some parts. Based on the data got from observation checklists, it was found that the were improvements of students' involvement from the first meeting to the next meeting till the last one as presented in Table 3.

Table 3: The Result of Observation Checklist

Meeting $\begin{gathered}\text { Acquired } \\ \text { score }\end{gathered} \quad$ Percentage




\begin{tabular}{lll}
\hline 1 & 23 & 71.87 \\
\hline 2 & 25 & 78.12 \\
\hline 3 & 27 & 84.37 \\
\hline 4 & 28 & 87.5 \\
\hline
\end{tabular}

Based on the data got from the observation checklists and field notes, the description of findings got in each meeting could be described as follow. In the first meeting, generally the teaching learning process which the teacher implemented all the steps that she had planned before as mentioned in lesson plan ran well till the end of the lesson. Though, when the researcher/ teacher came to the class at the beginning of the lesson, the class was so dirty and untidy so the researcher asked them to clean the class first to create better and comfortable place to learn. It took a long time (15 minutes) to make it clean and tidy. As the result, some students felt tired after cleaning the class and were not ready to get the lesson at that time. This situation made the teacher shortened the time for doing some activities and gave more attention to the students who were not ready to study.

During the lesson, there were some problems found since students were not really involved during teaching learning process. It was found that there were a few students who still did not pay attention to teacher's explanation since they enjoyed chatting with their friends as usual. Teacher had to repeat her explanation and ask questions to check students' understanding. It was done to make sure that they would be ready and familiar with graphic organizers and how to comprehend the text after using that graphic organizer. Besides, some students got difficulties in comprehending teacher's instruction and a few of them did not understand teacher's instruction, but they were reluctant to ask to the teacher. They did like to ask their friends, sometimes it ended with a joke or chatting with them. Teacher had to warn them many times.

However, generally many of them liked doing the task since they were enthusiastic working in group, eventhough others did not want to join the group because they did not like their group members. In grouping, some leaders of the group were dominant and answered all the questions by themselves till the teacher reminded and asked them to do their own duty. It seemed they did not believe on her/his group members' answers. Consequently, a few of group members were not involved in discussion since they did not do the task and did not understand their duty. At the end of the lesson, most of them looked happy and felt successful in completing the task in groups.

Next, in the second meeting, The class was in good condition, it seemed that the students were ready to learn. The teacher did the steps as planned in the lesson plan. In this meeting, the teacher asked students to work in team, pair and solo. The students were more enthusiastic in listening teacher's explanation and instruction; it seemed that they thought the steps were a little bit familiar enough. Some students still did not want to ask questions to the teacher since they were reluctant to speak, but others tried to ask questions to the teacher whenever they need to clarify their understanding. 
The students were more enthusiastic in working in group and tried to complete their own task by themselves since the leader and the others were more familiar with the responsibility they had. Even though, a few were still reluctant to do his/her duty. He/she asked her/his friend to complete their task. The teacher was better enough in giving the instructions to the students to make it clearer. More students were involved in group discussion since they knew what they had to do as the members and the leaders were more able to lead the discussion. They listened to their friends' answer and ask questions and clarification from friends.

In pairing, the students did the task well; they made their own graphic organizers about the text and answers the questions given by the teachers related to the text. However, the graphic organizers made by many students were not various, it seemed they imitate the example given before and most of the sentences were copied from the text as the original one that sometimes those could not represent the main ideas. In the next step, many students had tried to revise or check their partner's work, but others did not want to read their partner's work and only said all were correct. They did not discuss their answer, they just copied their friend's answer whenever they thought that their friend's answer was better than hers/his. The teacher had to ask the students to discuss it. The teacher then did discussion to check and clarify students' work. In individual, some students were good enough in revise and make their work better after reading and consulting their partner's work. Students were happy with their work after completing the task.

Then, in the third meeting, the teaching learning process ran well as a whole, almost all students paid attention to the teacher's instruction and explanation. Students were ready to study and do the activities. There was one student who felt bored with the activities done, while others were still enthusiastic with the strategy used by the teacher. In this meeting, at the beginning of the lesson, teacher told to the students that they can ask anything that they have not understand yet and get good score whenever they were active in the class. It was effective since more students tried to ask questions to the teacher whenever they got confused during the process in this meeting, though they did it by using their first language. More students responded teacher's instruction soon.

In groups, students were more active in discussion, though most of the time they also still used their first language. They were more enthusiastic in commenting their friends answers and asking clarification about their comments. In pairing, they did the task better since the teacher told them to give more extra points for whom gave good comments and revision to their friend's work. More students were more enthusiastic in revising their work and asked more suggestion or idea from their partner.

Last, in the end of the cycle or in the fourth meeting, the lesson ran well. The task and activities done were completed more quickly. Students were more active in group and pairing. There was a student suggest to use the other strategy, it seemed he felt bored with the same activities done. However, most of students still got interest learning and doing the same task. The students still used their first language in interacting with the teacher or their friends. The graphic organizers made 
by the students were more various. They were more creative in creating their own graphic organizers. They were also better in performing their works in front of their group member.

Based on those findings it could be inferred that this strategy could help students and could share what they had to their friends as well. Students could strengthen each other with what they had. It was good for class such as the class used in this study which consisted of many heterogeneous students where the students could help, teach and tutor their friends who had weaknesses in some parts. The strategy was combined with the use of graphic organizers to give better effect since graphic organizers help the students in comprehending the structure and the information of texts.

\section{Team}

In this phase, after doing preactivity and discussing the vocabulary related to the text, students were asked to work in group of four. Discussing vocabulary or important words before was needed to help students in comprehending the text more easily and develop their skill that is guessing the meaning of word. Next, each group had to comprehend the text by answering some questions given by the teacher related to the text. Each member of a group answered different question (leading questions), which means one student answers one questions, after reading the text individually and silently. It was done to lead the students to the content of the text generally, it could help them in comprehending text better. Based on the findings, the students did well, though in the beginning there were some students who did not take responsibility to answer the questions. It was done by the leaders themselves. The teacher had to remind the students and give a kind of reward to motivate them to get involved in answering questions. It was effective till the second, third and final meeting when more students answered their questions by themselves in groups. They were more enthusiastic in doing the activity. Most of them asked questions and clarifications to their friends. It seemed they were happy in working in group. They loved this part of this activity.

Then, they discussed the answers one by one and the topic of the text (one student in group led group discussion, she/he was chosen by the teacher, they were high achievers based on the data from preliminary study). This step was conducted to give clarification and discuss their answers so that they could catch the idea about the text as a whole. This was good to help the students in building and developing their reading ability step by step by tutoring. They can share how to find information from the text. In short, the activities done in team ran well as expected and the students were actively involved in team work. It was achieved by encouraging the students and assisting them when they got difficulties in doing the task. They were more enthusiastic in doing the activities. The activities in this phase helped them to build their understanding about the text and prepare themselves to do the next activities in pairs.

\section{Using Graphic Organizers in Pair}


In general, the students were also active while they were working in pairs. Each of them reread the text while they were creating their own graphic organizers for the text they read and answered questions based on the text. They could create any kind of graphic organizers they wanted based on their understanding about the text freely based on the model explained by the teacher in the first meeting. For the first time, the students' graphic organizers were as same as the example modeled in the previous meeting. It seemed that they were just tried to imitate what they had learned before. Besides, the content of their graphic did not really represent the idea that they meant. Some were still confused in deciding what words/phrase/ clause/sentences they should put in their graphic organizers. However, those became more various since the teacher reminded them to use or create their own variations as mentioned by the teacher in the previous lesson. They were more enthusiastic and creative in creating their own. It was good to use graphic organizers generated by the students because it also could improve their creativity as suggested by the previous researcher (Kim, Vaughn, et al, (2004)).

Then after they had finished their task, they swapped what they had made and read their friend's graphic organizers and discussed the answers. This activity was done to share ideas and help in giving improvement in peer' understanding toward the text. At the beginning of the cycle, it did not run well, the teachers should assisted and reminded the students about what they had to do and gave more motivation to them. They gave feedback (compliment, correction, or additional information) about them. Each pair did discussion about what their partners wrote in her/his graphic or comment given by her/his partner in her/his graphic organizer to get clarification about it. They could do this activity well since they were more familiar with the activities and the motivation given by the teacher.

Based on the findings presented previously in this part, the activities done in pair ran well as expected. Most of the students were active, though; there were problems at the beginning. However, it could be solved by encouraging the students and assisting them when they got difficulties in doing the tasks and motivate them to do the tasks better. They were more enthusiastic in doing the activities. This phase helped them in understanding the text and creating strategic tools, graphic organizers. It also helped them to answer the questions related to the text which asked them to find information in the text and prepare themselves to do the next activities in solo phase.

\section{Using Graphic Organizers in Solo}

The last phase that was solo by employing graphic organizers also ran well. The students worked individually to make their work better based on their friend's feedback. At the beginning of the cycle, some students did not do the activities, but they did it well after. Last, teacher asked the students to retell the text by using their graphic organizers orally in groups. The students were creative in retelling the text by using their graphic organizers. They were happy after completing the task since they could do it well and had more self confidence after following the steps previously. Based on the findings, the steps in this phase ran well. 


\section{Students' Perceptions toward the Strategy}

The data on students attitude toward the use of graphic organizers through Team-Pair-Solo strategy to improve reading comprehension ability of eighth graders were collected from the questionnaire that were distributed to the students in the fifth meeting, May $22^{\text {nd }} 2015$. Based on the result, it was found that for the first until the fourth statement which was related to more general feeling toward the steps and activities during the process most of the students or more than $90 \%$ of students responded positively toward the statements given. For the first statement, there were $46.88 \%$ students who strongly agreed with this statement, $46.88 \%$ agreed, only $6.25 \%$ did not really agree and nobody disagreed. Similar with that, for the second statement, $78.13 \%$ students who strongly agreed, $15.63 \%$ agreed, only $3.13 \%$ did not really agree and $3.13 \%$ disagreed. It was also found for the third statement, $93.75 \%$ of them strongly agreed, $6.25 \%$ agreed with the statement, and nobody disagreed. While for the fourth one, all of them $100 \%$ strongly agreed with the statement that the steps used made them uneasy to give up. It meant that most of them agreed that the steps used in this strategy made them happy to learn that gave them motivation and self confidence in learning.

Then, from the fifth to the last statements which were related to know students' perception about how the steps or activities done could help them in comprehending the texts, its structure and information, it was also found that generally students also responded positively toward the statements given. For the fifth statement, there were $87.5 \%$ students who strongly agreed with this statement, $9.38 \%$ agreed, only $3.13 \%$ did not really agree and nobody disagreed. For the sixth statement, there were $87.5 \%$ students who strongly agreed, $12.5 \%$ agreed, and nobody disagreed. Similar with the result of the previous statement, for the seventh statement, it was found that $81.25 \%$ students strongly agreed, $18.75 \%$ agreed, and nobody disagreed. It was also found for the eighth statement, $84.38 \%$ of them strongly agreed, $12.5 \%$ agreed with the statement, $3.13 \%$ did not really agreed and nobody disagreed. For the ninth one, it was as same as the sixth one. While for the last one, it was found that $90.63 \%$ students strongly agreed, $9.38 \%$ agreed that the steps used helped them in memorizing the information got from the text. Based on these results, it could be seen that the students thought that the strategy or the steps used in teaching learning process could help them in comprehending the text, its structure and information.

Based on the data obtained about the students perceptions toward the strategy presented in the previous section, the researcher sum up that nearly all the students that participated in this study gave positive perceptions toward the implementation of graphic organizers through Team-Pair-Solo strategy in teaching reading. Most of them agreed that the strategy used made them happy, to learn that gave them motivation, and self confidence in learning. However, the most obvious 
one is that all the students (100\%) strongly agreed that the strategy used avoid them from desperation. It was in line with Lev Vygotsky as cited in Kagan and Kagan ( 2009: 4.8), working in group does help learners to develop their skills or ability, so it can avoid them from desperation since peers help them to be more confidence and have good motivation than teacher. Besides, they also thought positively that the strategy used in this study could help them in comprehending the text, its structure and information. They felt happy while they were learning by using this strategy and could help them in comprehending the text.

\section{Reflection}

Based on the data obtained in research findings; students' achievement in reading comprehension test, observation checklists, field notes and questionnaire, the researcher did a reflection. As presented in the previous section, In term of the product where the data got from the result of reading comprehension test, the average score of students achievement after implementing the strategy was improved and there were more than $80 \%$ students who passed the minimum passing score, i.e. 70. Next, in term of process, which the data collected from observation checklists, field notes and questionnaire, it was found that more than $80 \%$ students are actively involved during the process using this strategy and respond positively toward the strategy. Based on this reflection, it could be concluded that in Cycle I the researcher by employing the strategy could reach all the criteria of success; hence she did not need to go the next cycle.

\section{CONCLUSION AND RECOMMENDATIONS}

On the basis of research findings and discussion explained in the previous section, it can be concluded that strategy of employing graphic organizers through Team-Pair-Solo strategy improved reading comprehension ability mainly in recount text of the eighth graders of SMPN 9 Kubung. The strategy employed encompasses the following steps: (1) working in group of four, each of which has to comprehend the text by answering some leading questions, (2) discussing the answer one by one and the topic of the text, (3) working in pairs, (4) creating their own graphic organizers and answer questions based on the text, (5) swapping their work and discussing the answers, (6) giving feedback, (7) discussing the feedback, (8) revising the work, (9) retelling the text by using their graphic organizers orally in groups.

It was proved that most of students could achieve the minimum passing score and all of them can improve their score. Besides, the students' involvement during teaching learning process improved since before the implementation of the strategy until the last meeting of the implementation which most of them (more than $80 \%$ ) were actively involved. In addition, the students also showed positive perceptions toward the implementation of the strategy used in improving their reading comprehension abilit as recorded from the questionnaire.

Referring to the previous conclusion and to follow up the positive findings of the study, the researcher has some suggestions. For the teachers, they should be aware in 
managing the time for doing activities in teams, pairs and solo. Then, it is really useful to make the students are aware the advantages of using graphic organizers in comprehending a text and they should get the various of model first to make them more familiar with the strategy used in reading. Last, the teacher should be careful in choosing the appropriate text with good structure especially for teaching the learners who are still in the beginning level. It is useful to avoid them getting much confused in creating the graphic organizers.

Meanwhile, for the future researchers, it is suggested that they used the result of this study as reference in doing similar study and they combine the use graphic organizers to various types of texts. Especially, for one who will do the research in the upper level since it is more challenging to do and make them more creative and build their critical thinking. So, by challenging them to create more various graphic organizers gives them more opportunity to take advantage from this tool. In short, it is good to improve their creativity and their critical thinking as well.

\section{REFERENCES}

Cahyono, B.Y., \& Widiati, U. (2006). The Teaching of EFL Reading in the Indonesian Context.
TEFLIN Journal, Volume 17, Number1, February 2006. Retrieved on February $1^{\text {st }}$, 2015 from http://journal.teflin.org/index. php/journal/article/view/58/5 $\underline{2}$

Chang, K. E., Sung, Y. T \& Chen I. D. (2002). The Effect of Concept Mapping to Enhance Text Comprehension and Summarization. The Journal of Experimental Education, 71(1): 5-23.

Ellis, E. (1998). Q\&A: What's the Big Deal with Graphic Organizers? Retrieved on February $1^{\text {st }}$, 2015 from www.GraphicOrganizers.com.

Guri, R. S. (1989). Effects of a Tree Diagram on Students' Comprehension of Main Ideas in an Expository Text with Multiple Themes. Reading Research Quarterly, 24, 236-247. Retrieved on March $31^{\text {st }}, 2015$ from http://www.jstor.org/discove r/10.2307/747866? sid $=2110$ 6304329473 \&uid $=3738224 \&$ uid $=4 \&$ uid $=2$

Hall, T., \& Strangman, N. (2002). Graphic organizers. Wakefield, MA: National Center on Accessing the General Curriculum. Retrieved November $10^{\text {th }}, 2014$. from http://aim.cast.org/learn/ historyarchive/backgroundpa pers/graphic_organizers\#.Uvf vVOJdVwo 
Kagan, S., \& Kagan, M. (2009). Kagan Cooperative Learning. San Clamente, CA.: Kagan Publishing.

Keene, C. M. (2009). Effects of Graphic Organizers on Reading Achievement. Retrieved on November $10^{\text {th }}, 2014$ from www.valdosta.edu.

Kim, A. H., Vaughn, S., Wanzek, J., \& Wei, S. (2004). Graphic Organizers and Their Effects on the Reading Comprehension of Students with LD: A Synthesis of Research. Journal of Learning Disabilities, 37(2). Retrieved on February $1^{\text {st }}, 2015$ from http://www.parentcenterhub. org/repository/abstract21/

Kumaravadivelu, B. (2003). Beyond Method: Macrostrategies for Language Teaching. New Haven.: Yale Language Series.

Latief, M. A. (2013). Research Methods on Language Learning.: An Introduction. Malang: UM Press.

Manoli, P. \& Papadopoulou, M. (2012). Graphic Organizers as a Reading Strategy: Research Findings and Issues. Creative Education 2012. Vol.3(3), 348 -356. Retrieved on February $1^{\text {st }}, \quad 2015$ from http://www.SciRP.org/journal lc.

Nunan. D. (2003). Practical English LanguageTeaching. New York.: Mc Graw Hill.
Ogunleye, B.O. (2011). "Team Pair Solo" Cooperative Learning and Personality Type as Determinants of Students' Achievement and Attitude to Chemistry. An International Multidisciplinary Journal, Ethiopia, Vol. 5 (6), Serial No. 23, November, 2011. Retrieved on February $1^{\text {st }}$, 2015 from http://dx.doi.org/10.4314/afr rev.v5i6.22

Richard, J. C., \& Renandya, W. A. (2002). Methodology in Language Teaching : An Anthology of Current Practices. Cambridge.: $\quad$ Cambridge University.

Sasson, D. (2007). Six Tips for Teaching Lower Level. Retrieved on June $21^{\text {st }}, 2009$ from http://itesl.journal.org. 
Urquhart, A. H., \& Weir, C. J. (1998). Reading in a Second Language: Process, Product, and Practice. London.: Longman.

Vekiri, I. (2002). What is the Value of Graphical Displays in Learning? Educational Psychology Review, 14, 261312. Retrieved on March $31^{\text {st }}$, 2012 from http://deepblue.lib.umich.edu /bitstream/handle/2027.42/ 44453/10648 2004_Article_374334.pdf?seq uence $=1$ \&isAllowed $=y$ 